УДК 811.161.1'243:004.031.42

DOI https://doi.org/10.26661/2522-4360-2021-2-11

\title{
ВИКОРИСТАННЯ ІНТЕРАКТИВНИХ ТЕХНОЛОГІЙ НА ЗАНЯТТЯХ ІЗ РОСІЙСЬКОЇ МОВИ ЯК ІНОЗЕМНОЇ (НА МАТЕРИАЛІ ТЕРМІНОЛОГІЇ БУДІВНИЦТВА)
}

\author{
Яремчук С. М. \\ викладач кафедри іноземних мов \\ Національний університет «Львівська політехніка» \\ вул. Степана Бандери, 12, Львів, Україна \\ orcid.org/0000-0002-5648-7466 \\ kochanyja@gmail.com
}

Ключові слова: інтерактивна вправа, рольова гра, термінологія будівництва, російська мова як іноземна, ситуативні завдання.
У процесі вивчення термінології актуальним є розроблення різноманітних інтерактивних технологій та використання ігор, що забезпечує студентам-іноземцям усебічний розвиток мовлення в умовах, наближених до реальних, розуміння важливості правильного використання термінолексем. Організація інтерактивного навчання передбачає моделювання життєвих ситуацій, використання рольових ігор, проведення дебатів, дискусій, спільне вирішення проблеми на основі аналізу відповідної ситуації.

Ігри - один із найактивніших методів навчання мови, який забезпечує розвиток мовлення, формування та вдосконалення умінь і навичок комунікації в різноманітних близьких до реальних ситуаціях, сприяє підвищенню зацікавленості студентів у вивченні спеціальної лексики, зокрема термінології. Викладач у грі може бути керівником i режисером, виконувати функції одного з гравців, бути стороннім спостерігачем.

У статті проаналізовано методи та прийоми використання інтерактивних вправ та ігор у процесі вивчення спеціальної лексики російської мови. Подано та обгрунтовано найдоцільніші та найефективніші комунікативні завдання для засвоєння термінології будівництва на заняттях з іноземцями.

Заняття 3 мови як іноземної потрібно будувати так, щоб кожен iз запропонованих видів роботи виконував свою роль у формуванні певного комунікативного вміння, щоб студенти успішно оволоділи i діалогічним, і монологічним мовленням, спираючись на знання граматики, підвищували рівень культури мовлення в різних ситуаціях спілкування.

Коли в навчанні мови як іноземної застосовувати інтерактивні ігри, то це позитивно впливає на весь навчально-виховний процес, оскільки вони дають змогу залучити кожного учасника до обговорення проблеми. Це сприяє розвитку критичного мислення, уміння відстоювати свою позицію. Іноземці набувають навичок співпраці, колективного пошуку рішень, беруть активну участь у навчанні та передаванні своїх знань іншим людям. На основі використання ігор забезпечується інтеграція теорії та практики, набувається досвід у вирішенні проблемних завдань, забезпечується інтенсивний обмін досвідом і знаннями між учасниками команд і можливість порівняти свої знання і дії з іншими, а також уміння координувати ці дії. 


\title{
THE USE OF INTERACTIVE TECHNOLOGIES DURING LESSONS OF RUSSIAN AS A FOREIGN LANGUAGE (USING MATERIAL OF TERMINOLOGY OF CONSTRUCTION)
}

\author{
Yaremchuk S. M. \\ Lecturer at the Department of Foreign Languages \\ National University "Lviv Politechnic" \\ Stepana Bandery str., 12, Lviv, Ukraine \\ orcid.org/0000-0002-5648-7466 \\ kochanyja@gmail.com
}

Key words: interactive exercise, role-playing game, construction terminology, Russian as a foreign language, situational tasks.

\begin{abstract}
In the process of studying terminology, it is important to develop a variety of interactive technologies and the use of games, which provides foreign students with comprehensive speech development in conditions close to real, understanding the importance of proper use of terminology. The organization of interactive learning involves modeling life situations, the use of role-playing games, debates, discussions, joint problem solving based on the analysis of the situation.

Games are one of the most active methods of language learning, which not only provides speech development, formation and improvement of communication skills in a variety of close to real situations, but also helps to increase students' interest in learning special vocabulary, including terminology. The teacher in the game can be a leader and director, perform the functions of one of the players, be an outside observer.

The article analyzes the methods and techniques of using interactive exercises and games in the process of studying the special vocabulary of the Russian language. The most expedient and most effective communicative tasks for mastering the terminology of construction in classes with foreigners are presented and substantiated.

Classes in a foreign language should be built so that each of the proposed types of work plays a role in the formation of a certain communication skills, so that students successfully master both dialogic and monologue speech, based on grammar, increase the culture of speech in different communication situations. When interactive games are used in foreign language teaching, it has a positive effect on the whole educational process, as they allow to involve each participant in the discussion of the problem. It promotes the development of critical thinking, the ability to defend their position. Foreigners acquire skills of cooperation, collective search for solutions, take an active part in learning and transferring their knowledge to other people. Based on the use of games, the integration of theory and practice is provided, experience in solving problems is gained, intensive exchange of experience and knowledge between team members and the opportunity to compare their knowledge and actions with others, as well as the ability to coordinate these actions.
\end{abstract}

Вступ. Сьогодні освіта $€$ антропоцентричною. Переважає особистісно орієнтований підхід до навчання, за якого важливе місце приділяється методам і формам навчання, що сфокусовані на студенті (рольові ігри, диспути, робота в групах та ін.). Це забезпечує перехід від авторитарної до гуманістичної освітньої парадигми. Дослідження вчених-педагогів доводять, що ці «методи і форми навчання успішно формують не тільки спеціальні уміння та навички, а й загальноосвітні способи розумових дій - планувальні, розумові, сприяючи розвитку творчих і логічних навичок особистості» [4, с. 58].

У процесі вивчення термінології актуальною $\epsilon$ розробка різних інтерактивних технологій $\mathrm{i}$ використання ігор. Це забезпечує іноземцям різнобічний розвиток мови в умовах, близьких до реальних, розуміння важливості правильного використання термінолексем. Це ще раз підтверджує тенденцію зближення процесу навчання 3 життям, отримання на заняттях саме тих знань із мови, термінології, ділової етики, які необхідні 
слухачам для майбутнього проживання в російському соціокультурному просторі і подальшої професійної реалізації. Використання інтерактивних методів під час вивчення російської та української мов вивчало багато мовознавців і педагогів. Л. Ампілогова, О. Пометун, О. Когут розглядали інтерактивні технології в загальних рисах $[1 ; 5 ; 6]$. Н. Васильєва розглядала особливості використання інтерактивних методів навчання на уроках предметів гуманітарного циклу [2]. Л. Вишнякова зупинилася на ділових іграх на заняттях 3 російської мови як іноземної [3]. Однак невивченими залишаються аспекти застосування інтерактивних вправ для засвоєння спеціальної лексики.

Мета статті - продемонструвати можливості використання ігор на заняттях із російської мови як іноземної під час вивчення термінології будівництва; дати опис деяких інтерактивних методів і прийомів навчання, а також висвітлити методику ïх проведення. Мета зумовлює вирішення таких завдань: проаналізувати та підібрати найпродуктивніші завдання для навчання термінології будівництва; проілюструвати нерозривний зв'язок теорії і практики викладання російської мови як іноземної, зокрема під час вивчення термінології будівництва.

Теоретичне обгрунтування проблеми. Організація інтерактивного навчання передбачає моделювання життєвих ситуацій, використання рольових ігор, проведення дебатів, дискусій, спільне вирішення проблеми на підставі аналізу відповідної ситуації. «Під час інтерактивного навчання студенти вчаться вільно спілкуватися 3 іншими людьми, критично мислити, приймати продумані рішення» [7, с. 40].

Не применшуючи ролі орфографії і пунктуації на підставі традиційного зорового сприйняття тексту з пропущеними буквами і знаками пунктуації, не можна недооцінювати види робіт, які наближають заняття до природних умов мовної діяльності, зокрема ситуативні вправи, ігри (імітаційні, ділові, рольові, командні, сюжетні, гривправи і ін.), взаємний опитування в парах, творчі роботи різних форм і тематики.

Ігри - один із найбільш активних методів навчання мови, який забезпечує не тільки розвиток мовлення, формування і вдосконалення умінь і навичок комунікації російською мовою в різних, близьких до реальних, ситуаціях, але і сприяє підвищенню зацікавленості студентів у вивченні спеціальної лексики мови, зокрема термінології. Викладач у грі може бути центром, керівником i режисером; виконувати функції одного з гравців; бути стороннім спостерігачем.

Виклад основного матеріалу дослідження. Найбільш корисними і найбільш продуктивними на заняттях 3 російської мови як іноземної під час вивчення термінології будівництва $€$ інтерактивні ігри. Наприклад, інтерактивну гру «Мікрофон» доцільно використовувати на етапі визначення мети і структури заняття після оголошення теми і вступного слова викладача. Роль уявного мікрофона може виконувати ручка або олівець. Слово дають тільки тому, хто отримує цей уявний мікрофон. Відповіді студентів повинні бути лаконічними і швидкими, їх не коментують i не оцінюють. Обов'язковою є візуальне сприйняття теми. Використання технології «Мікрофон» буде доречним під час вивчення теми «Свойства строительных материалов» («Властивості будівельних матеріалів»). Викладач називає певний термін, а іноземці коротко і лаконічно пояснюють його значення i, якщо можливо, використання. Наприклад: абразивность - свойство твердого тела стирать другое тело или самому стираться в процессе трения; адгезия - взаимное прилипание двух разнородных твердых тел или жидкостей во время их контактов; гидроизоляция - защита разных сооружений и отдельных конструкций от вредного влияния воды; теплоизоляция - защита домов, тепловых установок, трубопроводов от теплопотерь или тепловых влияний; искусственный сделанный руками человека.

Вдосконаленню знань із правопису термінів будівництва сприяє гра «Найди пару» («Знайди пару»). Ї̈і слід проводити на початку уроку як орфографічну розминку на етапах узагальнення i систематизації вивченого матеріалу, повторення. Цінність цієї гри в тому, що вона вимагає від іноземців застосування багатьох правил. На дошці або на екрані (див. таблицю) записані слова, наприклад, синоніми - власне російські слова i запозичені. Іноземці читають ці слова, з'єднують їх стрілочками, пояснюють, чому саме ці слова утворюють пару:

\begin{tabular}{|c|c|}
\hline показатель & лофт \\
\hline сопротивление & продукт \\
\hline распылитель & фрагментация \\
\hline дробление & спрей \\
\hline изделие & резистентность \\
\hline чердак & индикатор \\
\hline
\end{tabular}

Гра «Знайди пару» допомагає розвинути в іноземців аналітичні здібності, сформувати орфографічну пам'ять, забезпечує усвідомлене використання правил правопису. Цю гру можна проводити як в усній, так і в письмовій формах. Вона сприяє підвищенню зацікавленості студентів у вивченні російської мови, зокрема спеціальної термінології.

Засвоєнню та розумінню термінологічної лексики будівництва сприяє також завдання скласти словничок на запропоновані теми, наприклад: «Стекло», «Керамика», «Цемент». Завдання можна ускладнити, якщо попросити студентів ввести 
записані слова у словосполучення чи речення, наприклад: керамика - керамические изделия изделия из глины называют керамикой, а керамическое производство называют гончарством; стекло - разноцветное стекло - из стекла изготавливают бутылки, вазы, столы и другие изделия.

Під час вивчення термінології будівництва заняття потрібно планувати так, щоб іноземці могли не тільки засвоїти якомога більше термінів, але і вміли використовувати їх у різних комунікативних ситуаціях, під час сприйняття, відтворення інформації й побудови власних висловлювань із дотриманням норм російської мови. Для збагачення словникового запасу i використання в мовленні необхідних термінолексем слід також включити гру «Четвертый лишний» («Четвертий зайвий»). Завдання гравців - проаналізувати запропонований ряд із чотирьох елементів i назвати зайвий, а саме той, у якого немає ознаки, властивої іншим, наприклад:

1. Нефть, газ, уголь, мазут.

2. Механик, инженер, строитель, архитектор.

3. Песок, раствор, щебень, цемент.

4. Чердак, подвал, пол, бельэтаж.

Свою відповідь студент обов'язково повинен пояснити, тому що принципів відбору є кілька: 1 мазут - продукт из нефти (среди природных ископаемых); 2 - механик - занимается ремонтом, а не проектированием и строительством; 3 - раствор состоит из песка, цемента, щебеня и воды; 4 - пол это покрытие, а не часть постройки.

Заняття з мови слід будувати так, щоб кожен із запропонованих видів роботи виконував свою роль у формуванні певного комунікативного вміння, щоб студенти успішно оволоділи і діалогічним, i монологічним мовленням, спираючись на знання граматики, підвищували свій рівень культури мовлення в різних ситуаціях спілкування. Потрібно моделювати діалоги відповідно до запропонованої ситуації спілкування. Це повністю відповідає меті та змісту сучасного мовної освіти і комунікативному підходу до навчання, яке відбувається через дію (чим ближче ігрова діяльність студентів до реальної ситуації, тим вище ії навчально-пізнавальна ефективність). Ігрова модель навчання покликана реалізувати, крім головної дидактичної мети, ще й інші завдання, а саме: допомогти в розвитку творчої уяви, дати можливість висловити свої думки.

Рольова гра - імітаційна форма активного навчання, яка вимагає мінімум витрат часу на iii розробку i впровадження. Під час вирішення психолого-педагогічних завдань і ситуацій вона неймовірно ефективна. Головна мета використання цієї форми - розвиток в іноземців аналітичних здібностей, прищеплення умінь приймати правильні мовні рішення.

Арсенал інтерактивних ігор досить великий, але найпоширенішими 3 них є завдання на моделювання. Кожна така гра відбувається за певною схемою: іноземців вводять у ситуацію, на підставі якої вони отримують нове завдання i виконують відповідні ролі. Після закінчення сценарію обговорюють те, що трапилося, щоб іноземці усвідомили отриманий досвід на теоретичному рівні.

Створення ситуативних завдань $є$ наслідком практичної реалізації теорії мовної діяльності 3 метою формування в іноземців мовленнєвих умінь:

1) урахування ситуації спілкування, адресата мовлення, мети і місця спілкування;

2) уміння формувати задум майбутнього висловлювання, використовуючи лексичний (зокрема термінологічний) та граматичний матеріал;

3) уміння сформулювати тему, головну думку, вибрати форму і стиль висловлювання;

4) уміння підібрати потрібні мовні засоби (синоніми, антоніми) з урахуванням всіх складових частин мовної ситуації.

Система ситуативних вправ має багато переваг над звичайними навчальними вправами, тому що ситуація мовного спілкування сприяє усвідомленому розумінню основних граматичних понять, а рішення граматичного завдання стимулює мовленнєву творчість. Доречними будуть також під час вивчення термінології будівництва такі ситуативно-моделювальні завдання, як: інтерв'ювання, складання оголошення або рекламного тексту, наприклад:

Задание 1. Составьте текст рекламы новопостроенного загородного домика, который вы собираетесь продавать. Используйте представленные слова.

Шифер, кирпич, обои, ламинат, бетон, лак, отопление, освещение, лоджия, балкон, мансарда, камин, ограда, гараж.

Задание 2. Возьмите интервью в штукатура и спросите его, с какими инструментами он работает (молоток, троянка, скарпель, кельма, скребок, ковш, шпатель).

Такі завдання є проміжним етапом між теоретичним ознайомленням із термінологією будівництва та їі практичним використанням в певних життєвих ситуаціях.

Результати. Викладач, активізуючи навчальний процес, повинен однаково володіти різними навичками і вміннями, без наявності яких, навіть розібравшись у технологіях, здійснювати їх в аудиторії важко, а розраховувати на успіх тим більше не доводиться. Це пов'язано з тим, що організація ігрового процесу вимагає від викладача володіння різними видами діяльності. Він повинен вміти координувати роботу всіх ігрових груп (внутрішньокомандну і міжгрупову), керувати міжгруповою дискусією, коментувати події, надавати допомогу і моральну підтримку гравцям, давати експертну оцінку змісту роботи, контролювати виконання норм і правил. Після доведення всіх запланованих дій до кінця і виконання всіх прогнозованих планів викладач повинен здійснити «зворотний зв’язок», провести анкетування, моніторинг, щоб виявити 
міру задоволення слухачів і ефективність отриманих умінь і навичок.

Чи не кожен викладач, який намагається впроваджувати інтенсивні ігрові технології в навчальний процес, здатний усвідомити необхідність спеціальної ігротехнічної компетентності. Практика свідчить, що більшість викладачів спочатку пробують застосовувати ігрові технології, а вже потім розуміють, що інтерактивних технологій треба серйозно навчатися, як і будь-яких інших знань.

Викладач (організатор гри) повинен не тільки знати питання і області діяльності, які моделюються у грі, а й вміти вести гру, контролювати ігровий режим, моментально реагувати на екстремальні ситуації, керувати конфліктними ситуаціями, коригувати гру на ходу. Крім цього, гру треба вести практично по пам'яті, відповідно, потрібно дуже добре знати всі ролі і сценарії ігор. Управління всім цим процесом вимагає неабияких здібностей і таких компетентностей, як здатність до аналізу та прогнозування, рішучість, швидкість реакції, мобільність, вміння вести свою лінію та позитивно впливати на людей.

Висновки. Якщо під час вивчення мови як іноземної застосовувати інтерактивні ігри, це позитивно вплине на весь навчально-виховний процес, оскільки вони допомагають залучити кожного учасника до обговорення проблеми. Це сприяє розвитку критичного мислення, діалогічного мовлення, вміння відстоювати свою позицію. Іноземці отримують навички кооперації, колективного пошуку рішень, беруть активну участь у навчанні і передачі своїх знань іншим людям. Таким чином, досягається головна мета інтерактивного навчання: «Те, що я чую, я забуваю. Те, що я бачу і чую, я трохи пам'ятаю. Те, що я чую, бачу і обговорюю, я починаю розуміти. Коли я чую, бачу, обговорюю і роблю, я здобуваю знання і навички. Коли я передаю знання іншим, я стаю майстром» [7, с. 12]. На підставі використання ігор на заняттях із російської мови як іноземної забезпечується інтеграція теорії і практики, підвищується зацікавленість студента у використанні додаткової літератури, набувається досвід у вирішенні проблемних завдань, забезпечується активна участь іноземця в колективній справі, інтенсивний обмін досвідом і знаннями між учасниками команд і можливість порівняти свої знання і дії з іншими, а також вміння координувати ці дії.

Хоча інтерактивні вправи і вимагають великої кількості часу як студента, так і викладача, однак результат від занять з їх використанням стає стимулом для подальшої роботи із цими методами навчання.

\section{ЛІТЕРАТУРА}

1. Ампілогова Л.А. Інтерактивні технології. Завуч. 2004. № 30. С. 13-15.

2. Васильєва Н.С. Застосування інтерактивних методів навчаня на уроках предметів гуманітарного циклу. Управліня школою. 2005. № 34. С. 18-22.

3. Вишнякова Л.Г. Использование деловых игр в преподавании русского языка как иностранного. Москва : Издательство Московского университета, 1987. 110 с.

4. Інтерактивні технології на уроках української словесності / Укл. Р. Орищин. Тернопіль : Підручники і посібники, 2006. 106 с.

5. Інтерактивні технології навчання: теорія, практика, досвід : методичний посібник / Укл. : О. Пометун, Л. Пироженко. Київ : А.С.К., 2002. 136 с.

6. Когут О.І. Інтерактивні технології навчання. Тернопіль : Астон, 2005. 203 с.

7. Щербина В.І. Інтерактивні технології на уроках української мови та літератури. Харків : Основа, 2005. 96 с.

\section{REFERENCES}

1. Ampilohova L. A. (2004). Interaktyvni tekhnolohii [Interactive Technologies] // Zavuch, 30. P. 13-15 [In Ukrainian].

2. Vasylieva N. S. (2005). Zastosuvannia interaktyvnykh metodiv navchania na urokakh predmetiv humanitarnoho tsyklu [Application of Interactive Teaching Methods at Lessons of Subjects of a Humanitarian Cycle] // Upravlinia shkoloiu - School management, 34. P. 18-22 [In Ukrainian].

3. Vyshniakova L. H. (1987). Ispolzovaniye delovyh igr v prepodavanii russkogo yazyka kak inostrannogo. [The Use of Business Games in Teaching Russian as a Foreign Language]. Moskva: Izdatelstvo Moskovskogo unsversiteta - Moscow University Press, 110 p. [In Russian].

4. Interaktyvni tekhnolohii na urokakh ukrainskoi slovesnosti [Interactive Technologies at Lessons of Ukrainian] / Ukl. R. Oryschyn. (2006). Ternopil: Pidruchnyky i posibnyky - Textbooks and manuals, 106 p. [In Ukrainian].

5. Interaktyvni tekhnolohii navchannia: teoriia, praktyka, dosvid: metodychnyi posibnyk [Interactive Learning Technologies: Theory, Practice, Expereince: Methodical Manual]. / Uk1.: O. Pometun, L. Pyrozhenko. (2002). Kyiv: A.S.K., 136 p. [In Ukrainian].

6. Kohut O. I. (2005). Interaktyvni tekhnolohii navchannia. [Interactive Learning Technologies]. Ternopil: Aston. 203 p. [In Ukrainian].

7. Scherbyna V. I. (2005). Interaktyvni tekhnolohii na urokakh ukrainskoi movy ta literatury. [Interactive Technologies at Lessons of Ukrainian Language and Literature]. Kharkiv: Osnova. 96 p. [In Ukrainian]. 